\title{
Which Matters More in Higher Education: Social Environment or Teaching Excellence? A Comparison Between Private and Public Universities
}

\author{
Sosyal Yaşam mı, Öğrenim Kalitesi mi: Yükseköğretimde Hangisi Daha Önemlidir? \\ Vakıf ve Devlet Üniversiteleri Arasında Bir Karşılaştırma \\ Önder Kethüda (iD) \\ Department of Tourism and Hotel Management, Akçakoca Vocational School, Düzce University, Düzce, Turkey
}

\begin{abstract}
Özet
Yükseköğretim kurumları arasında arzulanan nitelik ve nicelikte öğrenci çekmek için rekabet her geçen gün artmaktadır. Bu nedenle, üniversitenin kurumsal imajını ve öğrenci memnuniyetini ve öğrenci sadakatini etkileyen faktörlerin araştırılması önemlidir. Bu doğrultuda bu çalışmanın amacı, üniversiteler tarafindan öğrencilere sağlanan sosyal yaşam olanaklarının ve öğrenim kalitesinin üniversite kurumsal imajına, öğrenci memnuniyetine ve öğrenci sadakatine etkisini ortaya koymak ve sosyal yaşam ve öğrenim kalitesi değişkenlerinin bağımlı değişkenleri açıklama düzeylerini karşılaştırmaktır. Bu amaç doğrultusunda İstanbul'da bulunan 10 vakıf ve 5 devlet üniversitesinde kotalı örneklem yöntemi ile 829 öğrenciden veri toplanmıştrr. Veri seti Yapısal Eşitlik Modellemesi ile analiz edilmiştir. Araştırma sonucuna göre hem öğrenim kalitesinin hem de sosyal yaşamın üniversite kurumsal imajını ve öğrenci memnuniyetini doğrudan etkilemektedir. Ayrıca, hem öğrenim kalitesinin hem de sosyal yaşam değişkenleri öğrenci sadakatini kurumsal imaj ve öğrenci memnuniyeti değişkenleri üzerinden dolaylı olarak etkilemektedir. Modelde yer alan değişkenler arası etki katsayılarındaki farklılıklardan hareketle, üniversitelere önerilerde bulunulmuştur.
\end{abstract}

Anahtar sözcükler: Devlet üniversitesi, öğrenci memnuniyeti, öğrenci sadakati, öğrenim kalitesi, sosyal yaşam, üniversite imajı, vakıf üniversitesi.

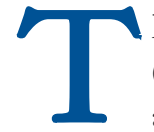
he competition among higher education institutions (HEIs) both to access financial resources and to attract targeted prospective students has never been fiercer (Carvalho \& de Oliveira Mota, 2010; Chapleo, 2005; Mazzarol \& Soutar, 2012; Widiputera, De Witte, Groot, \& van den Brink, 2017). Students, who are the customers of the service of HEIs (Bunce, Baird, \& Jones, 2017; Eagle \& Brennan, 2007; Guilbault, 2016; Tomlinson, 2018; Woodall, Hiller, \& Resnick, 2014), have a significant place in the process of pro-

\begin{abstract}
The competition among higher education institutions to attract and retain prospective students is constantly getting fiercer. Therefore, it is important to investigate the factors that affect student satisfaction, student loyalty, and perceived image of a university. This study aims to identify and compare the influence of social environment and teaching excellence provided to students on institutions' university image, student satisfaction, and student loyalty. The data were collected from 829 undergraduate students who were studying at 15 universities, 5 public and 10 private, in Istanbul. The data were analyzed by Structural Equation Modeling. The hypotheses were tested by using path analysis in AMOS and Independent Sample t-Test in SPSS. The results provide evidence that both social environment and teaching excellence have a direct significant influence on the image of a university and student satisfaction, together with an indirect influence on student loyalty through university image and student satisfaction. Some suggestions for higher education institutions are made based on the differences between coefficients among variables.
\end{abstract}

Keywords: Private university. public university, social environment, student loyalty, student satisfaction, teaching excellence, university image.

ducing and disseminating information, the fundamental reason for the existence of universities. Therefore, HEIs seek to achieve the sustainability of prospective students (Conway, Mackay, \& Yorke, 1988; Eagle \& Brennan, 2007). The sustainability of students is possible via recruiting a substantial number of prospective students and decreasing drop out ratio. Along with the marketing activities of HEIs, the satisfaction of current students and their loyalty to the institutions are critical for the sustainability of students (Schertzer \& Schertzer, 2004).
İletişim / Correspondence: Assist. Prof. Dr. Önder Kethüda Department of Tourism and Hotel Management, Akçakoca Vocational School, Düzce University, Düzce, Turkey e-mail: onderkethuda@duzce.edu.tr
Yükseköğretim Dergisi / Journal of Higher Education (Turkey), 11(1), 51-62. @ 2021 Deomed Geliş tarihi / Received: Ekim / October 2, 2018; Kabul tarihi / Accepted: Ağustos / August 30, 2020 Bu makalenin atıf künyesi / How to cite this article: Kethüda, Ö. (2021). Which matters more in higher education Social environment or teaching excellence? A comparison between private and public universities. Yüksekögrretim Dergisi, 11(1), 51-62. doi:10.2399/yod.19.021000 
Another important concept for marketing HEIs is the university image (Belanger, Mount, \& Wilson, 2002; Çetin, 2004; Kuo \& Ye, 2009; Luque-Martínez \& Del Barrio-García, 2009; Wilkins \& Huisman, 2014). A distinct university image has an impact on donations, cooperation with public and private institutions for research and development, and access to alternative financial resources (Chapleo, Carrillo Durán, \& Castillo Díaz, 2011; Ivy, 2001; Mount \& Belanger, 2004). It is also one of the most important factors affecting prospective students' choice and willingness to apply to an institution (Kethüda, 2017; Maringe, 2006; Maringe \& Carter, 2007; Price, Matzdorf, Smith, \& Agahi, 2003; Wilkins \& Huisman, 2014).

Many studies have been conducted on HEIs focusing on image, student satisfaction, and/or student loyalty. Some of those studies focus on the relationship between those three variables along with some antecedents and/or consequences. For example, Alves and Raposo (2007) tested the relationship between image, student satisfaction, and student loyalty along with their antecedents and consequences. The perceived value and perceived quality were antecedents, whereas word of mouth was a consequence in their research model. Tayyar and Dilşeker (2012) tested the same model without one of the antecedents, the perceived value. They also compared public and private universities in terms of all the variables including the research model. Mavondo, Tsarenko and Gabbott (2004) probed the mediating role of student satisfaction between the resources and the capabilities of the universities and the likelihood of students' recommending their institutions to other students. Helgesen and Nesset (2007), Brown and Mazzarol (2009), and Alves and Raposo (2010) investigated the relationship between images, student satisfaction, and student loyalty within higher education. In another study, Borden (1995) aimed to segment student markets with factors affecting student satisfaction. Browne, Kaldenberg, Browne and Daniel, (1998) examined the relationship between satisfaction and quality judgment of college services. To consider the issue from a different angle, Hennig-Thurau, Langer and Hansen (2001) tested the influence of relationship quality on student loyalty at universities.

This paper focuses on those three critical marketing concepts; i.e. university image, student satisfaction, and student loyalty, along with the social life and teaching excellence. Social life and teaching excellence represent two critical components of students' university experience. The present paper aims to compare the impact coefficients of social life and teaching excellence on three important marketing concepts for HEIs in both private universities and public universities. For this aim, firstly, the influences of teaching excellence and social environ- ment on university image, student satisfaction, and student loyalty need to be identified. Another purpose of this paper is to compare and contrast public and private universities in terms of all the variables in the research model. Understanding and comparing the effect of social life and teaching excellence on university image, student satisfaction, and student loyalty, which are three critical marketing concepts, are very important for HEIs in allocating resources at both public and private universities. The ultimate purpose of this study is to help develop university image and increase student satisfaction and loyalty by suggesting an optimum balance between social environment and teaching excellence in both public and private universities.

\section{Theoretical Background and Hypothesis}

\section{Student Loyalty}

Customer loyalty is a deep commitment to continue to buy a preferred product brand consistently among the alternatives in the future (Oliver, 1999). Customer loyalty refers to customers' willingness to maintain their relationship with goods or services offered by the company or the brand (Behara, Fontenot, \& Gresham, 2002). Customer loyalty also attributes to a positive attitude towards the brand and the high level of commitment that covers the customer's repeated purchase behavior. Oliver (1999) categorized loyalty level into four levels: cognitive, affective, conative, and action. Cognitive loyalty is the first phase of loyalty and it occurs when a brand is compared with the rivals according to its functional features such as price and quality and it is chosen over them. Since the functional features might be exceeded by the rivals at any time, this type of loyalty is the weakest, and Oliver (1999) stated that true loyalty starts after this phase of loyalty. Affective loyalty refers to the formation of influential feelings and emotions of customers such as brand satisfaction. Conative loyalty represents the tendency of the customer's recurring purchase and recommending the brand to others. Action loyalty, which is formed of the results of these three loyalty levels, is the strongest loyalty level and it refers to customers' endeavoring to protect the brand (Blut, Evanschitzky, Vogel, \& Ahlert, 2007). Customer loyalty can be evaluated from not only behavioral perspective but also cognitive and emotional perspectives since behavior patterns are associated with appreciation (Hennig-Thurau et al., 2001).

Customer loyalty in HE is called student loyalty (HennigThurau et al., 2001) since students are widely accepted as customers in the higher education sector. Student loyalty consists of behavioral and attitudinal dimensions like customer loyalty. The attitudinal dimension is composed of emotional, conative, and action loyalty phases, whereas the behavioral dimension refers to the cognitive loyalty phase. Student loyalty has the fol- 
lowing components: recommending a university to others; if starting anew, the likelihood of attending the same university; if attending new courses or further education, the likelihood of choosing the same university; willingness to keep in touch with the university, and willingness to become a member of the alumni organizations of the university (Brown \& Mazzarol, 2009; Browne et al., 1998; Helgesen, 2008; Helgesen \& Nesset, 2007; Hennig-Thurau et al., 2001).

\section{Student Satisfaction}

Customer satisfaction is a subjective summary judgment based on the customer's experiences compared with expectations (Oliver, 1980). Since students are widely regarded as the customer of the service provided by HEIs, student satisfaction can be defined parallel to customer satisfaction (Elliott \& Healy, 2001; Schertzer \& Schertzer, 2004). Student satisfaction refers to the favorability of a student's subjective evaluation of the various outcomes and other experiences associated with education (Elliott \& Shin, 2002). Student satisfaction corresponds to the degree to which the students feel fulfilled by judging how well the characteristics of the service provided pleasure through the education process in the campus environment (Amaro, Marques, \& Alves 2019; Borden, 1995). Students' overall satisfaction is being shaped not only by the experiences of students in the classroom but also all other experiences relating to campus life (Elliott \& Shin, 2002).

Student satisfaction is one of the most prominent antecedents of student loyalty (Amaro et al., 2019). Students whose expectations are met and are satisfied with the service have generally positive attitudes towards the institution and tend to recommend the institution to their peers. Therefore, many papers in the literature provide pieces of evidence that student satisfaction has a strong and direct impact on student loyalty (Alves \& Raposo, 2010; Brown \& Mazzarol, 2009; Browne et al., 1998; Carvalho \& de Oliveira Mota, 2010; Clemes \& Gan, 2008; Elliott \& Healy, 2001; Helgesen \& Nesset, 2007; Tayyar \& Dilşeker, 2012; Thomas, 2011). Based on this information, the following hypothesis was formulated:

$\mathbf{H}_{1}$ : Student satisfaction significantly influences student loyalty.

\section{University Image}

The corporate image is defined as the general impression that the public has about an institution. In this sense, university image can be defined as the sum of all the beliefs an individual has towards the university (Alcaide-Pulido, Alves, \& GutiérrezVillar, 2017; Alves \& Raposo, 2010). A university image is created a set of ongoing perceptions and/or memory inputs on dif- ferent image attributes. A single image, which can be interpreted as positive, neutral, or negative toward the institution, is the result of combinations of all image attributes on the minds of students and other shareholders.

It is hard for individuals wishing to study at an HEI to compare the service with competing ones since the characteristics of the service provided by HEIs are not easy to observe $(\mathrm{Ng} \&$ Forbes, 2009). University image is a critical signal for students to comprehend and interpret the unobservable characteristics of the higher education service (Erdem \& Swait, 1998; Kirmani \& Rao, 2000). Therefore, university image is a highly important factor for students while selecting a university to study (Aghaz, Hashemi, \& Sharifi Atashgah, 2015; Kethüda, 2017; Maringe, 2006; Maringe \& Carter, 2007; Price et al., 2003; Wilkins \& Huisman, 2014). Furthermore, university image significantly influences perceived service quality, perceived value, and the tendency to recommend the institution to others (Alves \& Raposo, 2007). In addition, it has a significant influence on student satisfaction and loyalty (Alves \& Raposo, 2010; Belanger et al., 2002; Brown \& Mazzarol, 2009; Hart \& Rosenberger, 2004; Helgesen \& Nesset, 2007; Masserini, Bini, \& Pratesi, 2019; Nguyen \& Leblanc, 2001; Palacio, Meneses, \& Pérez, 2002; Tayyar \& Dilşeker, 2012). Based on this information, the following hypotheses were formulated:

$\mathbf{H}_{2}$ : University image significantly influences student satisfaction.

$\mathbf{H}_{3}$ : University image significantly influences student loyalty.

\section{Teaching Excellence}

Teaching excellence refers to students' perceived quality of teaching at an institution. It consists of how well curricula and course contents were designed, how well students are prepared for work life after graduation, the accessibility and availability of lecturers, and the level of using modern tools in a teaching environment. Since the main purpose of higher education is to train young adults in a subject area or occupation, students purchase a teaching service that meets their expectations from the institution. Therefore, the natural outcome of a qualified teaching service is student satisfaction, since student expectations are met. Previous research has revealed that education quality had an influence on student satisfaction (Alves \& Raposo, 2007; Brown \& Mazzarol, 2009; Browne et al., 1998; Clemes \& Gan, 2008; Elliott \& Shin, 2002; Helgesen \& Nesset, 2007; Hennig-Thurau et al., 2001; Okumuş \& Duygun, 2008). Besides, there are studies focusing on the relationship between the general quality of higher education service and student satisfaction (Darawong \& Sandmaung, 2019; Kuo \& Ye, 2009; Masserini et al., 2019; Subrahmanyam, 2017). 
Because teaching quality is a component of service quality in higher education (Hennig-Thurau et al., 2001), it can be stated that teaching excellence has a significant effect on student satisfaction as well. Moreover, Schertzer and Schertzer (2004) noted that education quality had a direct impact on student satisfaction. On the other hand, the variables, which might be considered as the indicators of teaching quality such as the quality of lecturers (Helgesen \& Nesset, 2007; Hill, Lomas, \& Macgregor, 2003), the sufficiency of curriculum and course content (Hoyt \& Brown, 2003; Lo, 2010), communication between lecturer and students (Hill et al., 2003), and modern tools that are used while teaching (Lo, 2010), have significant influences on student satisfaction. Thomas (2011) found that academic success is the factor influencing student satisfaction the most. Based on the information above, the following hypothesis was developed:

$\mathbf{H}_{4}$ : Teaching excellence significantly influences (a) university image, (b) student satisfaction, and (c) student loyalty.

\section{Social Environment}

Social environment stands for social, cultural, sporting, and entertainment facilities and resources that are offered to students in a campus environment. Social environment is one of the most important factors for a prospective student in choosing a university (Çatı \& Bilgin, 2015; Çatı, Kethüda, \& Bilgin, 2016; Donaldson \& McNicholas, 2004; Price et al., 2003; Yamamoto, 2006). As noted by Borden (1995), student satisfaction with the experience in an institution depends on their interactions on campus. In addition, Elliott and Healy (2001) found that campus climate had a strong impact on students' overall educational experiences whereas campus life had a moderate impact. Besides, Schertzer and Schertzer (2004) highlighted that after educational quality, social environment was the second important factor affecting student satisfaction. Paswan and Ganesh (2009) highlighted that campus life and social interactions were the utmost indicators of student satisfaction. Torlak and Doğan (2011) argued that social environment on campus was one of the three important factors affecting students' brand perception of a university. Based on the above discussion, the hypothesis below was formulated:

$H_{5}$ : Social environment significantly influences (a) university image, (b) student satisfaction, and (c) student loyalty.

\section{Method}

This study was designed in an empirical framework by using quantitative methodology. The population of the study consists of undergraduate students in Istanbul. The data were collected from a group of students studying at 15 (5 public and 10 private) universities in Istanbul. It aimed to include the students studying at different faculties that accept students with different types of scores on the Higher Education Entrance Exam (YGS) in Turkey. To ensure heterogeneity of students in terms of their study field, the data were gathered from students studying at least three different faculties of the same university. For all the universities, the data were gathered from the students studying at least three different faculties except for Boğaziçi and İstanbul Ticaret universities. The highest amount of data were collected from the students at seven different faculties of Istanbul University, followed by Yıldız Technical University with six different faculties. In total, the participants were from 59 different faculties from 15 universities. The participants were students from the following schools of those universities: Engineering, Law, Architecture and Design, Economics and Administrative Sciences, Islamic Sciences, Dentistry, Business Administration, Pharmacy, Medicine, Humanities and Social Sciences, Business and Management, Natural Sciences, Commercial Sciences, Economics, Communication, and Science-Literature.

Quota sampling, which is one of the non-random sampling methods, was used while choosing the participants. Every faculty of universities was visited and the data were collected from the students who are willing to take part in a face-to-face survey. 40 participants from each university were determined as the target quota. Istanbul Bilgi University and Boğaziçi University were the universities with the lowest number of participants with 43 students while Marmara University and Istanbul University had the highest number, with 74 students each. The numbers of participants from different faculties ranged from 5 to 19 students. The data were collected from 829 participants in total.

The survey used to collect data consists of three main sections ( Appendix 1). In the first part, there are measures of university image, student satisfaction, and student loyalty. The measure of university image is taken from Nguyen and LeBlanc (2001). This measure consists of three items and its reliability (coefficient alpha $=0.76>0.70$ ) and validity (correlation coefficients within indices are generally greater than those between indices) has been proven. Student satisfaction and loyalty scales have been developed based on the works of Brown and Mazzarol (2009), Browne and others (1998), Helgesen (2008), Helgesen and Nesset (2007), and Hennig-Thurau and others (2001). Student satisfaction is made of four items and student loyalty consists of five items. The research that used those measures of student satisfaction and loyalty noted that their validity and reliability scores were acceptable. In the second part, there are scales to measure teaching excellence and social environment, adopted from Kethüda (2016). Teaching 


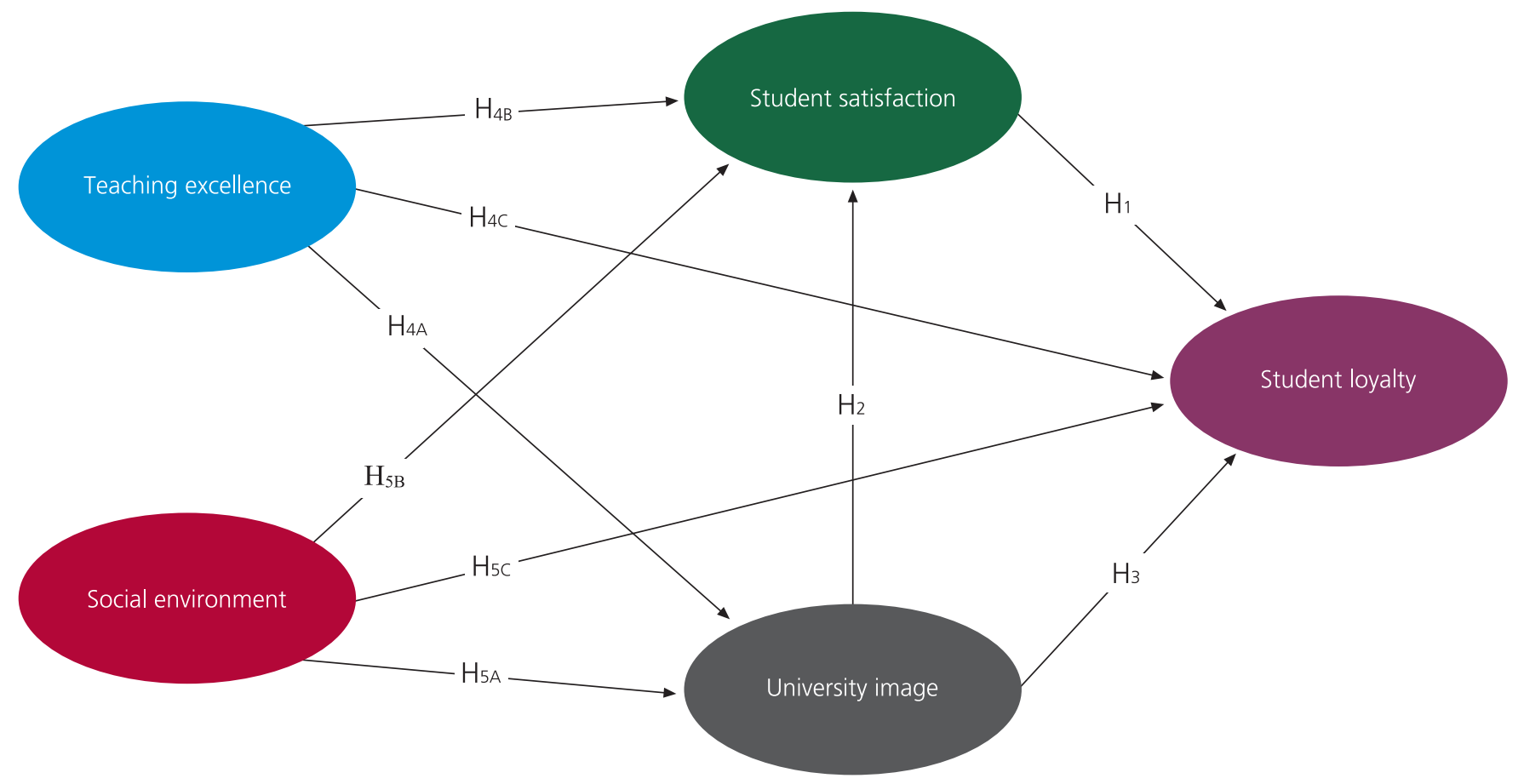

Figure 1. Theoretical model of the study.

excellence is a construct with six items and validity (factor loads of the items vary from 0.60 to 0.77 ) and reliability (coefficient $a l p h a=0.88>0.70)$ has been proven. Social environment is a construct with five items and its validity (factor loads of the items vary from 0.68 to 0.80 ) and reliability (coefficient alpha= $0.86>0.70)$ has been proven. All five aforementioned constructs were measured with the use of a five-point Likert-type agreement scale with the anchors of strongly disagree (1) and strongly agree (5).

The impact of teaching excellence and social environment on dependent variables and relations between dependent variables were tested as a whole model as presented in Figure 1. To test the model as a whole, AMOS, a variance-based Structural Equation Model (SEM), was used. Besides, to compare public and private universities in terms of all variables by independent sample $t$ test and to calculate the Cronbach's alpha values of the constructs, SPSS was used.

Descriptive characteristics of participants are critical for the generalizability of results. The mean value for the ages of the participants is 22 and its standard deviation is 2 . The oldest participant was 36 , and the youngest was 18 years old. The students who were in their first year at a university were not involved in the sample because they may not have had the opportunity to get to know the university very well. The students attending their second year comprised $14 \%$ of the participants, 54\% were in their third year, 29\% were in their fourth year, and $3 \%$ were either in their fifth or sixth year of their university education ( $\mathbf{\square i g u r e} 2)$.

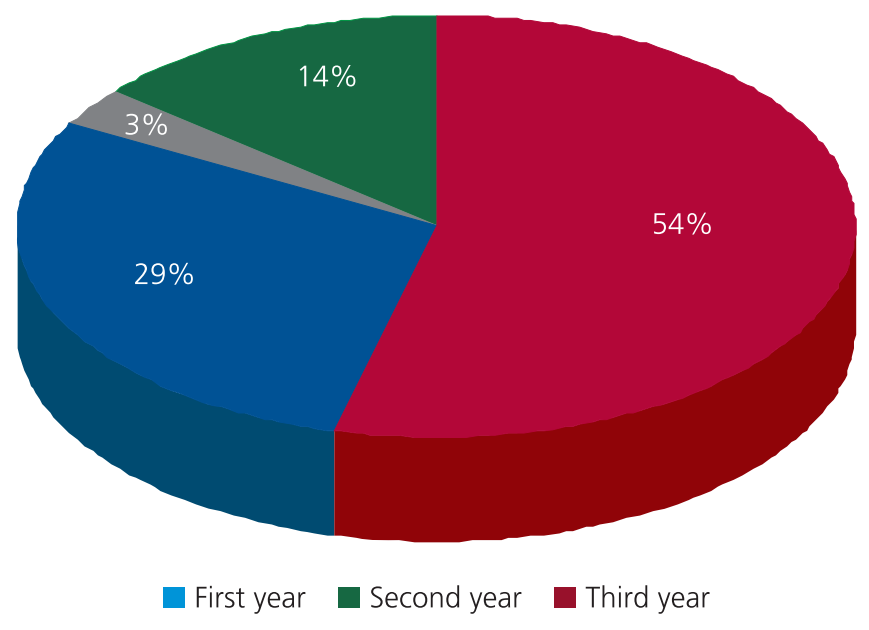

a Fourth year $\quad$ Fifth or sixth year

- Figure 2. Participants' year of study. 


\section{Results}

The data analysis had two steps, which are validating the measurement model of all constructs and testing the structural model ( $\square$ Figure 1) representing the correlations between these constructs. In the first step, Confirmatory Factor Analysis (CFA) was applied and the validity and reliability of the measurement model was evaluated. CFA is used for validating a measurement model that determines the relationship between observed indicators, and their underlying latent constructs. It shows how well a theoretical measurement model supports the data and enables the researcher to assess the construct validity and the reliability of variables. The measurement model consists of five latent variables and 23 items directly observed variables. Based on modification indices, two different covariances were created between two observed variables of student satisfaction and social environment, separately. After creating covariances, the model fit indices showing the overall fit of a model in SEM were evaluated. Researchers have a consensus that instead of one single measure of overall fit, evaluating different indices gives more accurate results. Chi-square $\left(\chi^{2}\right)$, degree of freedom $(D F)$, normed fit index (NFI), incremental fit index (IFI), comparative fit index (CFI), root mean square error of approximation (RMSEA), goodness of fit index (GFI), and adjusted goodness of fit index (AGFI) are model fit indices that are widely accepted. Chi-square value $\left(\chi^{2}=474.895\right.$; $p=0.00<0.05)$ indicates that the theoretical measurement model is different from the model generated by the data. However, this result might be accepted as normal due to the large sample size. In the cases like this, the ratio of chi-square to the degree of freedom $(D F=218)$ is evaluated. The ratio $\left(\chi^{2} / S D=2.671\right)$ is smaller than 3 , and it indicates a very good fit to the measurement model. Values of comparative fit indices, NFI (0.960), IFI (0.978), CFI (0.978), RMSEA (0.041), also indicate that the measurement model fits very well. Thus, the theoretical measurement model is supported by the dataset.

Values of composite reliability $(C R)$, which indicates the reliability of the data set, and Cronbach's alpha $(C A)$, which indicates the internal consistency, are much greater than the benchmark point (0.70). Based on these values, it can be argued that constructs are very reliable and their internal consistencies are quite high. Convergent and discriminant validities were evaluated to get an insight about the construct validity of the model. Regarding the convergent and discriminant validity, average variance extracted $(A V E)$, maximum shared variance $(M S V)$, and correlation coefficients between latent variables are shown in Table 1 . AVE is about convergent validity and its values since each variable is greater than the benchmark point (0.50). Discriminant validity is achieved when the value of $A V E$ is greater than the value of $M S V$ and the square root of $A V E$ value is greater than the correlation coefficients between latent variables. The values about the validity in Table 1 indicate that relations between each latent variable and their observed variables are quite good (convergent validity) and these relations are greater than the relations between latent variables (discriminant validity). Furthermore, the loading coefficients of all the observed indicators are higher than the benchmark point (0.60) and all of them are significant (Steenkamp \& van Trijp, 1991). These findings indicate that the measurement model achieves adequate validity and reliability and the structural model can be tested.

The proposed research model was tested by SEM using AMOS software. The structural model was tested while keeping the covariances that had been created, based on the modification indices of CFA. Fit indices belonging to the structural model are shown in $\square$ Table 2. Although the chi-square value of the model is significant, the ratio of the chi-square to the degree of freedom $(D F=218)$ indicates a perfect overall fit of the structural model. Besides, comparative fit indices and goodness fit indices of the structural model display that it fits very well as shown in Table 2 (Meydan \& Şeşen, 2015). Thus, the model is supported by the data.

- Figure 3 shows direct coefficients between variables in the model. The results indicate that teaching excellence has a direct significant influence on university image, satisfaction,

Table 1. Reliability and validity of the constructs.

\begin{tabular}{lccccccccccc} 
& Factor loads & Items & CR & CA & AVE & MSV & UI & SE & SL & SS & TE \\
UI & $0.79-0.84$ & 3 & 0.862 & 0.860 & 0.675 & 0.648 & 0.822 & & & \\
SE & $0.75-0.90$ & 5 & 0.915 & 0.919 & 0.685 & 0.425 & 0.530 & 0.827 & & \\
SL & $0.67-0.88$ & 5 & 0.902 & 0.905 & 0.650 & 0.648 & 0.801 & 0.559 & 0.807 & \\
SS & $0.84-0.90$ & 4 & 0.920 & 0.919 & 0.742 & 0.648 & 0.805 & 0.652 & 0.805 & 0.862 \\
TE & $0.62-0.79$ & 6 & 0.862 & 0.860 & 0.512 & 0.406 & 0.577 & 0.468 & 0.637 & 0.618 & 0.715 \\
\hline
\end{tabular}

AVE: average variance extracted; CA: Cronbach's alpha; CR: composite reliability; MSV: maximum shared variance; SE: social environment; SL: student loyalty; SS: student satisfaction; TE: teaching excellence; UI: university image. 
Table 2. Values of fit indices for the structural model.

\begin{tabular}{|c|c|c|c|c|c|}
\hline \multirow[b]{2}{*}{ Fit indices } & & \multicolumn{2}{|c|}{ Values } & \multirow[b]{2}{*}{ Good fit } & \multirow[b]{2}{*}{ Acceptable fit } \\
\hline & & Public & Private & & \\
\hline \multirow[t]{3}{*}{ Overall model fit } & $\chi^{2}$ & 339.56 & 379.09 & Not significant & - \\
\hline & $D F$ & 218 & 218 & - & - \\
\hline & $\chi^{2 / D F}$ & 1.558 & 1.739 & $\leq 3$ & $\leq 4-5$ \\
\hline \multirow[t]{4}{*}{ Comparative model fit } & $N F I$ & 0.937 & 0.946 & $\geq 0.95$ & $0.94-0.90$ \\
\hline & $|F|$ & 0.976 & 0.975 & $\geq 0.95$ & $0.94-0.90$ \\
\hline & CFI & 0.976 & 0.975 & $\geq 0.97$ & $\geq 0.95$ \\
\hline & RMSEA & 0.045 & 0.042 & $\leq 0.05$ & $0.06-0.08$ \\
\hline \multirow[t]{2}{*}{ Goodness of model fit } & GFI & 0.903 & 0.928 & $\geq 0.90$ & $0.89-0.85$ \\
\hline & AGFI & 0.877 & 0.909 & $\geq 0.90$ & $0.89-0.85$ \\
\hline
\end{tabular}

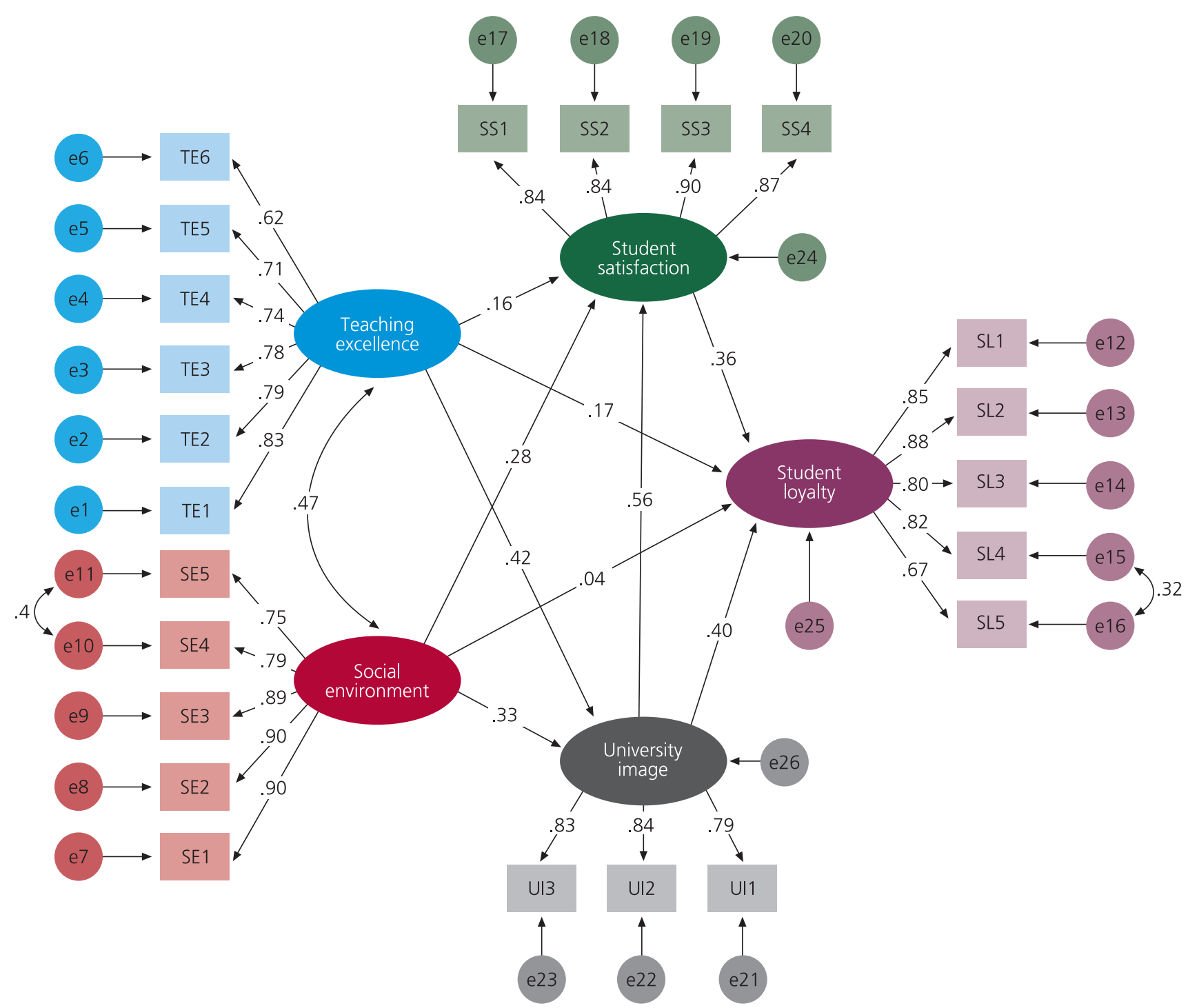

- Figure 3. Research model showing direct effects. 
Table 3. Standardized indirect and total coefficients between variables.

\begin{tabular}{|c|c|c|c|c|c|c|}
\hline \multirow[b]{2}{*}{ Variables } & \multicolumn{2}{|c|}{ University image } & \multicolumn{2}{|c|}{ Student satisfaction } & \multicolumn{2}{|c|}{ Student loyalty } \\
\hline & Indirect & Total & Indirect & Total & Indirect & Total \\
\hline Social environment & - & 0.33 & 0.19 & 0.47 & 0.30 & 0.33 \\
\hline Teaching excellence & - & 0.42 & 0.24 & 0.40 & 0.31 & 0.48 \\
\hline University image & - & - & - & 0.57 & 0.20 & 0.60 \\
\hline
\end{tabular}

and loyalty. However, the social environment has a direct significant influence on university image and student satisfaction. On the other hand, the university image has a direct significant effect on both satisfaction and loyalty, and satisfaction has a direct significant effect on loyalty. Except for the H5c hypothesis, all hypotheses were supported (C.R. $>1.96 ; p<0.05)$.

I Figure 3 displays the direct covariances between variables. However, the independent variables also have an indirect impact on the dependent variables through university image and/or student satisfaction. Table 3 shows indirect and total influences between variables. Both social environment and teaching excellence have an indirect effect on student satisfaction and loyalty through the university image. This indicates that university image is an important mediating variable on the effect of teaching excellence and social environment on student loyalty. Aside from the direct effect, the university image has an indirect effect on student loyalty through student satisfaction as well. These results highlight the importance of university image for marketing. Considering total effects, the results reveal that student loyalty is explained mostly by the university image. On the other hand, the social environment has more influence on student satisfaction, whereas teaching excellence has more influence on the university image. Moreover, student loyalty is influenced by teaching excellence and social environment approximately at the same level.

The research model was also tested separately by using the data from different types of universities, i.e. public and private universities, to unveil any differences between the coefficients of variables. Table 4 represents the coefficients in the model tested for the data from public and private universities separately. The results show that the effect of student satisfaction on student loyalty and the effect of university image on both student satisfaction and student loyalty are approximately at the same level in both types of universities. Besides, although the effect of teaching excellence on university image is the same in both types of universities, its effect on student satisfaction and student loyalty is higher in public universities than in private universities. In addition, there are negligible differences between public and private universities in terms of the effect of social environment on university image and student satisfaction. However, the social environment influences student satisfaction significantly in private universities, whereas it does not in public universities.

Another important issue that this paper seeks to answer is the comparison between student perceptions of the public and the private HEIs in terms of teaching excellence, social environment, student satisfaction, student loyalty, and university image.

Table 4. Standardized coefficients between latent variables on both public and private universities.

\begin{tabular}{|c|c|c|c|c|c|c|c|c|c|c|c|}
\hline & \multirow{2}{*}{$\begin{array}{l}\text { Dependent } \\
\text { variables }\end{array}$} & \multirow{2}{*}{$\begin{array}{l}\text { Independent } \\
\text { variables }\end{array}$} & \multicolumn{3}{|c|}{$\begin{array}{l}\text { In the private } \\
\text { universities }\end{array}$} & \multicolumn{3}{|c|}{$\begin{array}{l}\text { In the public } \\
\text { universities }\end{array}$} & \multicolumn{3}{|c|}{$\begin{array}{c}\text { In both } \\
\text { universities }\end{array}$} \\
\hline & & & Est. & C.R. & $p$ & Est. & C.R. & $p$ & Est. & C.R. & $p$ \\
\hline $\mathrm{H}_{1}$ & Student loyalty & Student satisfaction & 0.37 & 5.34 & $* * *$ & 0.35 & 3.09 & 0.00 & 0.43 & 7.41 & $* * *$ \\
\hline $\mathrm{H}_{2}$ & Student satisfaction & University image & 0.60 & 9.54 & $\star \star *$ & 0.53 & 9.01 & $\star * \star$ & 0.57 & 13.34 & $* * *$ \\
\hline $\mathrm{H} 3$ & Student loyalty & University image & 0.39 & 542 & $* * *$ & 0.33 & 3.73 & $* * *$ & 0.39 & 7.42 & *** \\
\hline $\mathrm{H}_{4} \mathrm{~A}$ & University image & Teaching excellence & 0.44 & 7.33 & $* * *$ & 0.44 & 5.65 & $* * *$ & 0.42 & 8.83 & $* * *$ \\
\hline $\mathrm{H}_{4 \mathrm{~B}}$ & Student satisfaction & Teaching excellence & 0.12 & 2.42 & 0.02 & 0.21 & 3.90 & $* * *$ & 0.16 & 4.55 & *** \\
\hline $\mathrm{H}_{4} \mathrm{C}$ & Student loyalty & Teaching excellence & 0.11 & 2.52 & 0.01 & 0.33 & 4.84 & $* * *$ & 0.17 & 4.86 & 0.00 \\
\hline $\mathrm{H} 5 \mathrm{~A}$ & University image & Social environment & 0.37 & 6.90 & $\star * *$ & 0.32 & 4.81 & $* * *$ & 0.33 & 7.85 & $* * *$ \\
\hline $\mathrm{H} 5 \mathrm{~B}$ & Student satisfaction & Social environment & 0.24 & 5.18 & $* * *$ & 0.31 & 6.52 & $* * *$ & 0.28 & 8.32 & *** \\
\hline $\mathrm{H} 5 \mathrm{C}$ & Student loyalty & Social environment & 0.12 & 2.69 & 0.01 & -0.06 & -1.01 & 0.31 & 0.04 & 1.34 & 0.18 \\
\hline
\end{tabular}

C.R.: critical ratio. 
Table 5. Comparison between the public and the private universities.

\begin{tabular}{|c|c|c|c|c|c|c|c|c|c|c|}
\hline \multirow[b]{2}{*}{ Variables } & \multirow{2}{*}{$\begin{array}{c}\text { Types of } \\
\text { HEls }\end{array}$} & \multirow[b]{2}{*}{$n$} & \multirow[b]{2}{*}{ Mean } & \multirow{2}{*}{$\begin{array}{c}\text { Mean } \\
\text { difference } \\
\text { (A-B) }\end{array}$} & \multicolumn{3}{|c|}{$\begin{array}{l}\text { Equality of } \\
\text { variances }\end{array}$} & \multicolumn{3}{|c|}{$\begin{array}{l}\text { t-test for equality } \\
\text { of means }\end{array}$} \\
\hline & & & & & & $\boldsymbol{F}$ & Sig. & $t$ & $d f$ & Sig. \\
\hline \multirow[t]{2}{*}{ Teaching excellence } & Private (A) & 427 & 3.41 & \multirow{2}{*}{0.19} & 1 & \multirow{2}{*}{3.47} & \multirow{2}{*}{0.06} & 3.10 & 700 & 0.00 \\
\hline & Public (B) & 275 & 3.22 & & 2 & & & 3.05 & 552 & 0.00 \\
\hline \multirow[t]{2}{*}{ Social environment } & Private (A) & 427 & 3.25 & \multirow{2}{*}{0.25} & 1 & \multirow{2}{*}{5.95} & \multirow{2}{*}{0.02} & 3.05 & 700 & 0.00 \\
\hline & Public (B) & 275 & 3.00 & & 2 & & & 3.00 & 551 & 0.00 \\
\hline \multirow[t]{2}{*}{ Student satisfaction } & Private (A) & 427 & 3.24 & \multirow{2}{*}{0.01} & 1 & \multirow{2}{*}{0.78} & \multirow{2}{*}{0.38} & 0.11 & 700 & 0.91 \\
\hline & Public (B) & 275 & 3.23 & & 2 & & & 0.11 & 568 & 0.91 \\
\hline \multirow[t]{2}{*}{ Student loyalty } & Private (A) & 427 & 3.14 & \multirow{2}{*}{-0.19} & 1 & \multirow{2}{*}{0.41} & \multirow{2}{*}{0.52} & -2.37 & 700 & 0.02 \\
\hline & Public (B) & 275 & 3.33 & & 2 & & & -2.36 & 577 & 0.02 \\
\hline \multirow[t]{2}{*}{ University image } & Private (A) & 427 & 3.31 & \multirow{2}{*}{-0.26} & 1 & \multirow{2}{*}{1.20} & \multirow{2}{*}{0.27} & -3.36 & 700 & 0.00 \\
\hline & Public (B) & 275 & 3.57 & & 2 & & & -3.33 & 563 & 0.00 \\
\hline
\end{tabular}

1: Equal variances assumed; 2: Equal variances not assumed.

To compare the mean values of those variables, Independent Sample t-test was used. The results of the analysis indicate that there are significant differences between the two types of universities in terms of all variables (i.e. teaching excellence, social environment, student loyalty, and university image) except for student satisfaction ( Table 5). The results of the analysis reveal that student perception of teaching excellence and social environment are significantly more positive in private universities than in public universities. On the other hand, the results point that the students at public universities are significantly more loyal than those at private universities. Furthermore, public universities have a significantly better university image than private universities.

\section{Discussion and Conclusion}

University image, student satisfaction, and student loyalty are very critical for marketing HEIs. They indicate not only how much students are satisfied with their experience at a university, but also the future success of student recruitment efforts, granting donations to a university, and finding public and private funds for research and development projects (Beneke, 2011; Chapleo et al., 2011; Ivy, 2001; Mount \& Belanger, 2004). Although marketing efforts have a significant effect on student recruitment, creating a university image and ensuring student satisfaction and loyalty are the best ways for the sustainability of attracting prospective students targeted in terms of quality and quantity (Dennis, Papagiannidis, Alamanos, \& Bourlakis, 2016).

The results indicate that university image is explained by both social environment and teaching excellence. However, teaching excellence is more influential on university image than is social environment. Furthermore, both social environment and teaching excellence have significant direct and indirect effects on student satisfaction. Also, student loyalty is significantly influenced by teaching excellence and not by social environment. On the other hand, student loyalty is indirectly influenced by both teaching excellence and social environment. These results generally support previous studies that were conducted about university image, satisfaction, and loyalty (Alves \& Raposo, 2007; Brown \& Mazzarol, 2009; Clemes \& Gan, 2008; Helgesen \& Nesset, 2007; Masserini et al., 2019; Paswan \& Ganesh, 2009). Considered all together, these results suggest that HEIs should invest in and develop not only teaching excellence, but also the social environment that they provide to their students.

The university image has a significant effect on loyalty both directly and indirectly. Taking into consideration the total values of direct and indirect coefficients, it might be argued that it is the most important concept in this study concerning student loyalty. It also has a significant effect on student satisfaction, which has a significant effect on student loyalty as well. These results support the study of Brown and Mazzarol (2009) and Masserini and others (2019), providing evidence that student satisfaction, a consequence of the perceived image of HEIs, is an antecedent of student loyalty. Concerning the direct effects, the results show that university image has the strongest effect on student satisfaction, which supports the work of Alves and Raposo (2010) highlighting university image as the most important construct to explain student satisfaction, which also has a significant effect on student loyalty.

One of the most interesting results of this study is that the social environment influences student satisfaction more than teaching excellence, whereas teaching excellence affects university image more than social environment. Another interesting 
result is that the social environment does not directly influence student loyalty significantly, despite the fact that it does indirectly through university image. On the other hand, teaching excellence affects student loyalty directly. The results demonstrate that teaching excellence and social environment do not have strong direct effects on student loyalty, yet they influence student loyalty through university image and student satisfaction indirectly. This finding shows that social environment and teaching excellence are not sufficient by themselves to ensure and maintain student loyalty. Student satisfaction and university image are a must to keep students loyal to a university, which means converting alumni into the strongest spokesperson for an institution. Taking the results above into consideration as a whole, HEIs targeting to increase student satisfaction are advised to invest their limited resources in social environment more than teaching excellence. On the other hand, HEIs that aim to improve only university image are recommended to make use of the resources to achieve teaching excellence. To conclude, universities that target student loyalty are suggested to develop and sustain both student satisfaction and university image.

Another notable result is that teaching excellence has more influence on student satisfaction and student loyalty in public universities than it has in private universities. On the other hand, the social environment has a greater influence on student loyalty in private universities than it has in public universities. Based on these results, while private HEIs mainly competing with public universities are advised to allocate their resources to the social environment, public universities mainly competing with private universities are advised to allocate their resources to teaching excellence.

The results also reveal that public universities have a better university image and student loyalty than private universities, whereas no significant difference was found between them in terms of student satisfaction. These results do not support the results of the research by Tayyar and Dilşeker (2012) indicating that private universities have a better university image, student satisfaction, and loyalty than public universities. The result that public universities have a better image than private universities might be explained via the fact that public universities in the sample of this study are among the oldest and most popular universities in Turkey. No significant difference between public and private universities in terms of student satisfaction might be explained with the subjective nature of satisfaction, which is a result of a comparison between expectations and experiences on students' minds. Public universities' having a better student loyalty than private universities might be explained by the fact that one of the most significant antecedents of student loyalty is the university image (Alves \& Raposo, 2010; Brown \& Mazzarol, 2009; Tayyar \& Dilşeker,
2012). On the other hand, private universities are better than public universities in terms of social environment and teaching excellence. This result indicates that private universities are more student-oriented than public universities in terms of teaching excellence and social environments for their students.

Some important limitations need to be considered while generalizing these results. Some variables like location, transportation, and campus type are related to the social environment that a university provides. Those variables were not included in this study. However, it would be interesting to include these variables in the research model. Further research might be conducted to investigate the effect of location and campus type on the dependent variables in this study.

Fon Desteği / Funding: Bu çalışma herhangi bir resmi, ticari ya da kar amacı gütmeyen organizasyondan fon desteği almamıştır. / This work did not receive any specific grant from funding agencies in the public, commercial, or not-for-profit sectors.

Etik Standartlara Uygunluk / Compliance with Ethical Standards: Yazar bu makalede araştırma ve yayın etiğine bağlı kalındığını, Kişisel Verilerin Korunması Kanunu'na ve fikir ve sanat eserleri için geçerli telif hakları düzenlemelerine uyulduğunu ve herhangi bir çıkar çakışması bulunmadığın belirtmiştir. / The author stated that the standards regarding research and publication ethics, the Personal Data Protection Law and the copyright regulations applicable to intellectual and artistic works are complied with and there is no conflict of interest.

\section{References}

Aghaz, A., Hashemi, A., \& Sharifi Atashgah, M. S. (2015). Factors contributing to university image: The postgraduate students' points of view. Fournal of Marketing for Higher Education, 25(1), 104-126.

Alcaide-Pulido, P., Alves, H., \& Gutiérrez-Villar, B. (2017). Development of a model to analyze HEI image: A case based on a private and a public university. Fournal of Marketing for Higher Education, 27(2), 162-187.

Alves, H., \& Raposo, M. (2007). Conceptual model of student satisfaction in higher education. Total Quality Management \& Business Excellence, 18(5), 571-578.

Alves, H., \& Raposo, M. (2010). The influence of university image on student behaviour. International Fournal of Educational Management, 24(1), 73-85.

Amaro, D. M., Marques, A. M. A., \& Alves, H. (2019). The impact of choice factors on international students' loyalty mediated by satisfaction. International Review on Public and Nonprofit Marketing, 16(2-4), 211-233.

Behara, R. S., Fontenot, G. F., \& Gresham, A. B. (2002). Customer process approach to building loyalty. Total Quality Management, 13(5), 603-611.

Belanger, C., Mount, J., \& Wilson, M. (2002). Institutional image and retention. Tertiary Education and Management, 8(3), 217-230.

Beneke, J. H. (2011). Marketing the institution to prospective students - A review of brand (reputation) management in higher education. International fournal of Business \& Management, 6(1), 29-44.

Blut, M., Evanschitzky, H., Vogel, V., \& Ahlert, D. (2007). Switching barriers in the four-stage loyalty model. Advances in Consumer Research, 34, $726-734$. 
Borden, V. M. H. (1995). Segmenting student markets with a student satisfaction and priorities survey. Research in Higher Education, 36(1), 73-88.

Brown, R. M., \& Mazzarol, T. W. (2009). The importance of institutional image to student satisfaction and loyalty within higher education. Higher Education, 58(1), 81-95.

Browne, B. A., Kaldenberg, D. O., Browne, W. G., \& Daniel, J. (1998). Student as customer: Factors affecting satisfaction and assessments of institutional quality. Fournal of Marketing for Higher Education, 8(3), $1-14$.

Bunce, L., Baird, A., \& Jones, S. E. (2017). The student-as-consumer approach in higher education and its effects on academic performance. Studies in Higher Education, 42(11), 1958-1978.

Carvalho, S. W., \& de Oliveira Mota, M. (2010). The role of trust in creating value and student loyalty in relational exchanges between higher education institutions and their students. Fournal of Marketing for Higher Education, 20(1), 145-165.

Chapleo, C. (2005). Do universities have "successful" brands? International Fournal of Educational Advancement, 6(1), 54-64.

Chapleo, C., Carrillo Durán, M. V., \& Castillo Díaz, A. (2011). Do UK universities communicate their brands effectively through their websites? Fournal of Marketing for Higher Education, 21(1), 25-46.

Clemes, M. D., \& Gan, C. E. C. (2008). University Student satisfaction: An empirical analysis. Fournal of Marketing for Higher Education, 17(2), $292-325$.

Conway, T., Mackay, S., \& Yorke, D. (1988). Strategic planning in higher education: Who are the customers? International Fournal of Educational Development, 8(6), 29-36.

Çatı, K., \& Bilgin, Y. (2015). A qualitative research on positioning of universities in Turkey. [Article in Turkish] Yïksekögretim Dergisi, 5(2), 91-102.

Çatı, K., Kethüda, Ö., \& Bilgin, Y. (2016). Positioning strategies of universities: An investigation on universities in Istanbul. Education and Science, 41(185), 219-234.

Çetin, R. (2004). Planning and implementing institutional image and promoting academic programs in higher education. Fournal of Marketing for Higher Education, 13(1-2), 57-75.

Darawong, C., \& Sandmaung, M. (2019). Service quality enhancing student satisfaction in international programs of higher education institutions: A local student perspective. Fournal of Marketing for Higher Education, 29(2), 268-283.

Dennis, C., Papagiannidis, S., Alamanos, E., \& Bourlakis, M. (2016). The role of brand attachment strength in higher education. Fournal of Business Research, 69(8), 3049-3057.

Donaldson, B., \& McNicholas, C. (2004). Understanding the postgraduate education market for UK-based students: A review and empirical study. International Fournal of Nonprofit and Voluntary Sector Marketing, 9(4), 346-360.

Eagle, L., \& Brennan, R. (2007). Are students customers? TQM and marketing perspectives. Quality Assurance in Education, 15(1), 44-60.

Elliott, K. M., \& Healy, M. A. (2001). Key factors influencing student satisfaction related to recruitment and retention. Fournal of Marketing for Higher Education, 10(4), 1-11.

Elliott, K. M., \& Shin, D. (2002). Student satisfaction: An alternative approach to assessing this important concept. Fournal of Higher Education, 24(2), 197-209.

Erdem, T., \& Swait, J. (1998). Brand equity as a signaling phenomenon. Fournal of Consumer Psychology, 7(2), 131-157.
Guilbault, M. (2016). Students as customers in higher education: Reframing the debate. Fournal of Marketing for Higher Education, 26(2), $132-142$.

Helgesen, Ø. (2008). Marketing for higher education: A relationship marketing approach. Fournal of Marketing for Higher Education, 18(1), 50-78.

Helgesen, Ø., \& Nesset, E. (2007). Images, satisfaction and antecedents: Drivers of student loyalty? A case study of a Norwegian University College. Corporate Reputation Review, 10(1), 38-59.

Hennig-Thurau, T., Langer, M. F., \& Hansen, U. (2001). Modeling and managing student loyalty: An approach based on the concept of relationship quality. Fournal of Service Research, 3(4), 331-344.

Hill, Y., Lomas, L., \& Macgregor, J. (2003). Students' perceptions of quality in higher education. Quality Assurance in Education, 11(1), 15-20.

Hoyt, J. E., \& Brown, A. B. (2003). Identifying college choice factors to successfully market your institution. College \& University fournal, 78(4), $3-10$.

Ivy, J. (2001). Higher education institution image: A correspondence analysis approach. International fournal of Educational Management, 15(6), 276-282.

Kethüda, Ö. (2016). The effect of brand positioning strategies for universities to student satisfaction and loyalty: A research on Universities in Istanbul. Düzce: Düzce University, Düzce Business School.

Kethüda, Ö. (2017). Segmenting international student market: An investigation in the United Kingdom. [Article in Turkish] Yiiksekögrretim Dergisi, 7(3), 186-196.

Kuo, Y.-K., \& Ye, K.-D. (2009). The causal relationship between service quality, corporate image and adults' learning satisfaction and loyalty: A study of professional training programmes in a Taiwanese vocational institute. Total Quality Management \& Business Excellence, 20(7), 749762

Lo, C. C. (2010). How student satisfaction factors affect perceived learning. Fournal of the Scholarship of Teaching and Learning, 10(1), 47-54.

Luque-Martínez, T., \& Del Barrio-García, S. (2009). Modelling university image: The teaching staff viewpoint. Public Relations Review, 35(3), $325-327$.

Maringe, F. (2006). University and course choice: Implications for positioning, recruitment and marketing. International fournal of Educational Management, 20(6), 466-479.

Maringe, F., \& Carter, S. (2007). International students' motivations for studying in UK HE: Insights into the choice and decision making of African students. International Fournal of Educational Management, 21(6), 459-475.

Masserini, L., Bini, M., \& Pratesi, M. (2019). Do quality of services and institutional image impact students' satisfaction and loyalty in higher education? Social Indicators Research, 146(1-2), 91-115.

Mavondo, F. T., Tsarenko, Y., \& Gabbott, M. (2004). International and local student satisfaction: Resources and capabilities perspective. Fournal of Marketing for Higher Education, 14(1), 41-60.

Mazzarol, T., \& Soutar, G. N. (2012). Revisiting the global market for higher education. Asia Pacific Fournal of Marketing and Logistics, 24(5), $717-737$.

Meydan, C. H., \& Şeşen, H. (2015). Yapısal eşitlik modellemesi: AMOS uygulamaları (2nd ed.). Ankara: Detay Publication.

Mount, J., \& Belanger, C. H. (2004). Entrepreneurship and image management in higher education: Pillars of massification. The Canadian fournal of Higher Education, 34(2), 125-140.

$\mathrm{Ng}$, I. C. L., \& Forbes, J. (2009). Education as service: The understanding of university experience through the service logic. Fournal of Marketing for Higher Education, 19(1), 38-64. 
Nguyen, N., \& LeBlanc, G. (2001). Image and reputation of higher education institutions in student's retention decisions. International fournal of Educational Management, 15(6), 303-311.

Okumuş, A., \& Duygun, A. (2008). Eğitim hizmetlerinin pazarlanmasında hizmet kalitesinin ölçümü ve algılanan hizmet kalitesi ile öğrenci memnuniyeti arasindaki ilişki. Anadolı Üniversitesi Sosyal Bilimler Dergisi, 8(2), $17-38$.

Oliver, R. L. (1980). A cognitive model of the antecedents and consequences of satisfaction decisions. Fournal of Marketing Research, 17(4), $460-469$.

Oliver, R. L. (1999). Whence consumer loyalty? fournal of Marketing, 63(Special Issue), 33-44.

Palacio, A. B., Meneses, G. D., \& Pérez, P. J. P. (2002). The configuration of the university image and its relationship with the satisfaction of students. Fournal of Educational Administration, 40(5), 486-505.

Paswan, A. K., \& Ganesh, G. (2009). Higher education institutions: Satisfaction and loyalty among international students. Fournal of Marketing for Higher Education, 19(1), 65-84.

Price, I., Matzdorf, F., Smith, L., \& Agahi, H. (2003). The impact of facilities on student choice of university. Facilities, 21(10), 212-222.

Schertzer, C. B., \& Schertzer, S. M. B. (2004). Student satisfaction and retention: A conceptual model. Fournal of Marketing for Higher Education, 14(1), 79-91.

Steenkamp, J. B. E. M., \& van Trijp, H. C. M. (1991). The use of lisrel in validating marketing constructs. International fournal of Research in Marketing, 8(4), 283-299.

Subrahmanyam, A. (2017). Relationship between service quality, satisfaction, motivation and loyalty: A multi-dimensional perspective. Quality Assurance in Education, 25(2), 171-188.

Tayyar, N., \& Dilşeker, F. (2012). The effect of service quality and image on student satisfaction at state and private universities. [Article in Turkish] Muğla Üniversitesi Sosyal Bilimler Enstitiisii Dergisi, 28, 184204.

Thomas, S. (2011). What Drives student loyalty in universities: An empirical model from India. International Business Research, 4(2), 183-192.

Tomlinson, M. (2018). Conceptions of the value of higher education in a measured market. Higher Education, 75(4), 711-727.

Torlak, Ö., \& Doğan, V. (2011). Assess the impact of prospective students' perceptions of university brand on their preferences for universities. Fournal of Management Faculty, 12(1), 97-113.

Widiputera, F., De Witte, K., Groot, W., \& van den Brink, H. M. (2017). The attractiveness of programmes in higher education: An empirical approach. European Fournal of Higher Education, 7(2), 153-172.

Wilkins, S., \& Huisman, J. (2014). Factors affecting university image formation among prospective higher education students: The case of international branch campuses. Studies in Higher Education, 7une 2014, $1-17$.

Woodall, T., Hiller, A., \& Resnick, S. (2014). Making sense of higher education: Students as consumers and the value of the university experience. Studies in Higher Education, 39(1), 48-67.

Yamamoto, G. T. (2006). University evaluation-selection: A Turkish case. International fournal of Educational Management, 20(7), 559-569.

Appendix 1. The questionnaire.

\section{Student Loyalty}

- I would recommend my university to others.

- I like to tell people about my university.

- If I do a postgraduate, I choose this university.

- I will keep in touch with this university after graduation.

- Being a member of the alumni organizations of this university is important to me.

University Image

- I have always had a good impression of this university

- In my opinion, this university has a good image in people's minds.

- I believe that this university has a better image than others.

Student Satisfaction

- This university generally meets my expectations.

- My experience at this university fits the ideal experience in my mind.

- Overall, I am very satisfied with this university.

- I think I did the right thing by choosing this university

Teaching Excellence

- The curriculum in my department is very well-formed.

- The teaching methods of the courses are adequate to meet students' needs.

- My education at this university prepares me for working life very well.

- Lecturers/faculties in my department are open to communication.

- The theory and practice are taught together at this university.

- Modern tools and facilities needed for the training are utilized in the learning process.

Social Environment

- The campus environment at this university is very attractive.

- There are adequate social and cultural activity areas on the university campus for students.

- The number of social and cultural activities organized in the university for students is sufficient.

- The university has adequate sports and recreational facilities.

- This university provides students facilities to do almost all sports branch

Bu makale Creative Commons Attribution-NonCommercial-NoDerivs 4.0 Unported (CC BY-NC-ND 4.0) Lisansı standartlarında; kaynak olarak gösterilmesi koşuluyla, ticari kullanım amacı ve içerik değişikliği dışında kalan tüm kullanım (çevrimiçi bağlantı verme, kopyalama, baskı alma, herhangi bir fiziksel ortamda çoğalttma ve dağıtma vb.) haklarılla açık erişim olarak yayımlanmaktadır. / This is an open access article distributed under the terms of the Creative Commons AttributionNonCommercial-NoDerivs 4.0 Unported (CC BY-NC-ND 4.0) License, which permits non-commercial reuse, distribution and reproduction in any medium, without any changing, provided the original work is properly cited.

Yayıncı Notu: Yayıncı kuruluş olarak Deomed bu makalede ortaya konan görüşlere katılmak zorunda değildir; olası ticari ürün, marka ya da kuruluşlarla ilgili ifadelerin içerikte bulunması yayıncının onayladığı ve güvence verdiği anlamına gelmez. Yayının bilimsel ve yasal sorumlulukları yazar(lar)ına aittir. Deomed, yayınlanan haritalar ve yazarların kurumsal bă̆lantıları ile ilgili yarg1 yetkisine ilişkin iddialar konusunda tarafsızdır. / Publisher's Note: The content of this publication does not necessarily reflect the views or policies of the publisher, nor does any mention of trade names, commercial products, or organizations imply endorsement by Deomed. Scientific and legal responsibilities of published manuscript belong to their author(s). Deomed remains neutral with regard to jurisdictional claims in published maps and institutional affiliations. 